\title{
ASSESSMENT OF THE CONDITIONS OF EDUCATIONAL FACILITIES IN SELECTED LOCAL GOVERNMENT AREAS IN KADUNA STATE, NIGERIA
}

\author{
Ezeamaka Cyril Kanayochukwu ${ }^{A^{*}}$, Bala Dogo ${ }^{B}$, Oluwole Olumide Akinwumi \\ Adewuyi Taiye Oluwafemi ${ }^{A}$, Joel Ajibuah ${ }^{A}$, Daful Mwanret ${ }^{A}$, Sadiq Queen ${ }^{A}$ \\ Received: May 6, 2020 | Accepted: June 27, 2020 \\ DOI: 10.5937/ZbDght2001081K
}

\begin{abstract}
This paper was aimed at examining the conditions of educational facilities in public schools in selected Local Government Areas in Kaduna State, Nigeria. Physical inventories were carried out using the Educational Facilities Assessment Form (EFAF). Multistage sampling technique was used to select 9 Local Government Areas (LGAs). Data were analyzed using Geographically Weighted Regression (GWR) 4.10 and Spearman Rank Correlation. The findings revealed that $88 \%$ of the schools do not have water supply while $22 \%$ have no roof, and $11.4 \%$ have power supply. It discovered that $32.9 \%$ of the schools were mud buildings while $4.2 \%$ has no structure and less than $24 \%$ has toilet facilities. Kaduna South LGA has the highest score (2.1) in the conditions of water facilities while Kajuru and Birnin Gwari LGAs have the lowest. Lere LGA has the least condition (1.1) of toilet facilities while Kaduna South LGA has the best (1.9). For conditions of building facilities, Zaria LGA was first followed by Kaduna South and Jemaá LGA. There was no significant relationship between public school and population of the LGAs, given that the calculated $t$-value (-0.222) was less than the critical $t$-value of $(0.267)$. The GWR revealed a significant association between age of schools and the conditions of educational facilities at 0.05 significance level. The paper concluded that the conditions of educational facilities are not in disarray and properly maintained due to poor funding thus, requires urgent action. It therefore, recommends the implication of the UNESCO's benchmark of demands $26 \%$ annual budget and $6 \%$ of the gross domestic product be invested in education.
\end{abstract}

Keyword: Assessment, Condition, Educational Facilities, Public Schools

A Department of Geography, Nigerian Defence Academy Kaduna, Nigeria; corresponding author: Ezeamaka Cyril Kanayochukwu, e-mail: cyrilezeamaka@gmail.com

B Department of Geography, Kaduna State University, Kaduna, Nigeria. 


\section{INTRODUCTION}

Education has proved to be the most effective tool in developing programmes that involve human beings. Such programmes cover decreasing mortality rates, increasing health awareness and empowering people to take charge of their destinies (Bhunia, Shit and Duaru, 2012). Education is a means of accessing broader social, economic, political, and cultural benefits due to its transformative and empowering potentials (Fabiyi and Ogunyemi, 2015). Educational facilities are vital resources that facilitate improved development of man and his environment. Educational facilities include materials, structures and amenities (Adamu, Baba-Gana and Emmanuel, 2015). Educational facilities such as land, buildings, furniture, and equipment contribute to a learning environment and classrooms in most of the schools were inadequate in terms of decency, space, and conveniences were not appropriately placed (Ayeni and Adelabu, 2012).

Many problems seem to have bedevilled the public educational system there by making them ineffective. Ayeni and Adelabu (2012) reported that inadequacy of classrooms in schools and poorly maintained school facilities constituted a major gap in the quality of learning environment. Public schools need to be efficient to be able to deliver the good tidings expected of them (Ahmed, 2003). The proper siting of schools and its facilities can serve a number of useful purposes to the state and people. For instance, it can reduce rural-urban migration since there are more schools with better educational facilities in urban area, thus enhancing the equalization of educational opportunities (Alabi and Ocholi, 2010).

There is a general belief that the conditions of facilities in schools and the environment have an important impact on education development and/or enrollment ratio. Educational facilities are needed to facilitate effective education development and learning. There is need for comprehensive information to help examine the gap in educational facilities in Kaduna State. Therefore, Kaduna State Government (KDSG) need to know of the conditions of her existing educational facilities within the state. This can help the state in analysing the current state of educational facilities and its progress in maintaining and redeveloping (re-modeling) the facilities in the educational sector in the state. However, the question should be if the existing or available schools have the required minimum standard of educational facilities? The problem of this paper is that the condition of educational facilities in Kaduna State does not meet the minimum standards as set aside by Federal Ministry of Education.

This paper proposed that one reason why the standards of education have fallen in the state is due to inadequate basic educational facilities in schools. The effect of the physical facilities on educational outcomes and its impact on the quality of schools is due of inadequacy of knowledge about these relationships. This paper preproposal that there is relationship between the age of the schools and the conditions of the educational facilities. Indeed, for governments to successfully enforce compulsory education, there must be assurances of access to educational facilities. The attempts by governments at various levels including Kaduna State Government to ensure that all children attend or return to school will not work without knowing the available and physical conditions of educational facilities in public schools. The aim of this paper is to examine the conditions of educational facilities in Kaduna State. 


\section{WHAT LITERATURE SAY?}

Bhunia et al. (2012) studied the assessment of school infrastructure at primary and upper primary level in West Bengai, India using a geospatial analysis and discovered that girl's toilet, electric, fence facilities are clustered in pattern at primary schools, and that electric and computer facilities found to be clustered distribution at secondary schools. In Nigeria, Archibong, Modi and Shepa (2015) studied the geography of infrastructure functionality at schools in Nigeria using spatial statistical techniques. There is a significant cluster of LGAs in the Northwest zone, outperforming LGAs in both other Northern and some Southern zones on all functionality indicators. Abdullahi and Wan Zahari (2015) examined the state of physical facilities of higher education institution in Nigeria and observed clearly that there are shortages of facilities in Nigerian tertiary institutions.

Adeyemi (2011) studied the enrolment analysis and the availability of physical facilities for the UBE Programme in Ekiti State, Nigeria and revealed that there is shortfall in the number of classes, number of lockers, number of chairs and school libraries. Ada (2005) revealed that there was low level of availability of physical facilities in primary and junior secondary schools in Delta State. Musa and Mohammed (2013) studied the distribution of primary and secondary schools in Bida, Niger State, Nigeria and the outcome revealed that there is deficiency in basic education facilities, while, quiet a number of the inhabitant have inadequate access to education in some part of Bida.

Olamiju and Olujimi (2011) studied the analysis of regional location of public educational facilities in the Akure region of Nigeria and revealed that Akure South had more public secondary schools than other parts of Akure. It revealed that these were informed by several conditions including school facilities, and absence of secondary schools. Izobo-Martins, Dare-Abel and Kunle, (2014) revealed that user attitude, maintenance culture, and lack of fund have major influence on existing infrastructures condition in public secondary school in Ado-Odo/ Ota LGA, Ogun State, Nigeria. Nyam Jim (2016) studied the locational analysis of public secondary schools in Kaduna Education Zone and observed that some of the schools had insufficient facilities.

Many studies have been carried out on the various aspects of school distribution and educational facilities. Nonetheless, not all researchers except for Nyam-Jim (2016), Archibong, Modi and Shepa (2015), Izobo-Martins, Dare-Abel and Kunle (2014) and Bhunia et al. (2012) were interested in the assessment of educational facilities. Thus, it has been observed that these studies did not provide information on availability and conditions of educational facilities in Kaduna State with regards to national minimum standards. These offers an opening for this kind and form bases for the research contribution to knowledge. 


\section{METHODS AND MATERIAL}

\section{Study Area}

Kaduna State is located at mid-central portion of the Northern parts of Nigeria and serves as a major gate way to important traditional, political and commercial states of Kano, Katsina, and Sokoto (Hena, 2014; Bako, Maiwada, Abubakar and Akwo, 2016). The Kaduna State is located between Latitudes $9^{\circ} 03^{\prime}$ and $11^{\circ} 32^{\prime}$ North of the Equator and Longitudes $6^{\circ} 05^{\prime}$ and $8^{\circ} 38^{\prime}$ East of the Greenwich Meridian. Kaduna State is bounded to the north by Katsina, Zamfara and Kano States, to the west by Niger State, to the east by Bauchi State and to the south by Plateau, Nassarawa and the Federal Capital Territory, Abuja (Figure 1). Its made up of 23 LGAs and Kaduna is the capital.

Kaduna State experiences a tropical continental climate with two distinct seasonal climates, dry and rainy seasons (Hena, 2014). The annual average rainfall in the state is about $1323 \mathrm{~mm}$. The average daily minimum and maximum temperatures are $15.1^{\circ} \mathrm{C}$ and $35.18^{\circ} \mathrm{C}$ (Nwude, 2006; Akpu, 2012; Hena, 2014; Bako et al., 2016). Kaduna State contains a striking range of natural environments from the forested Guinea Savanna and heavy rains in the Sothern part, to the Savanna scrub in the far north (Hena, 2014). The State extends from the tropical grassland known as the Guinea Savannah to Sudan Savannah (Nwude, 2006). Kaduna State is third most densely populated states in Nigeria. The population of the state according to 2006 National Census stands at 6,113,503

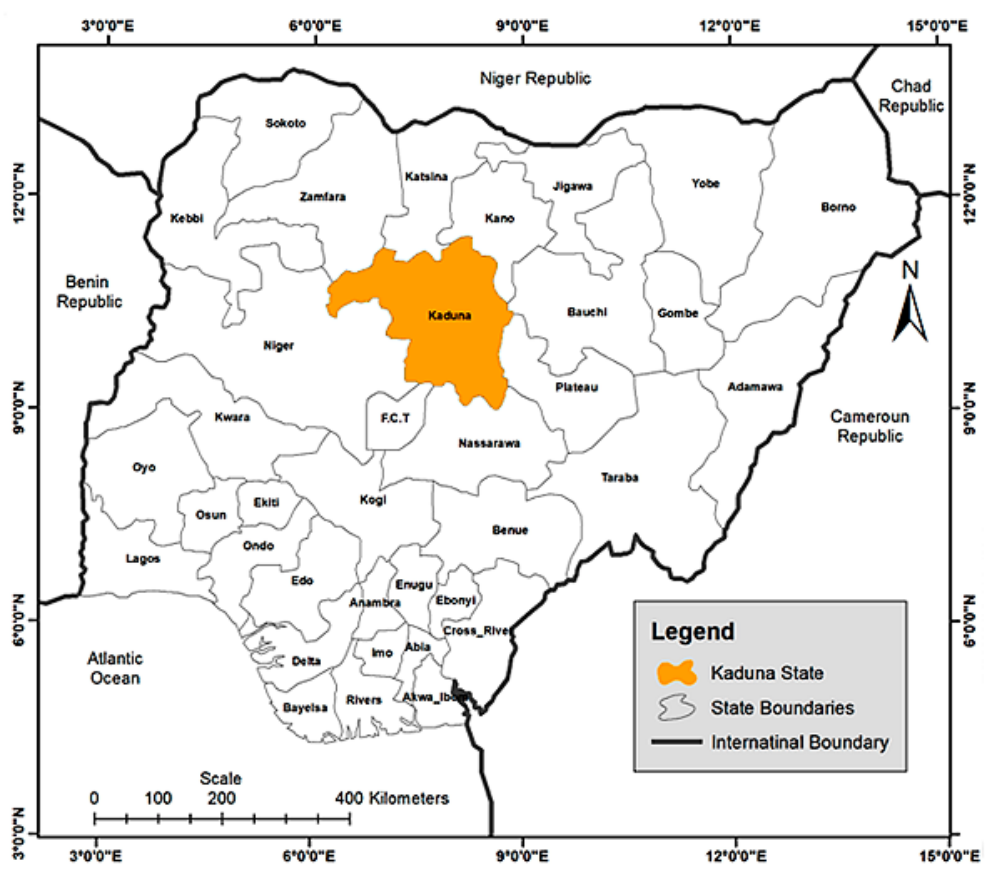

Figure 1. Kaduna State in Nigeria Source: KADGIS (2017) 
and has 3.18\% growth rate (National Population Commission, 2009) and 2017 projected population stands at 8,147,161 (KDSG, 2017; NBS, 2017).

\section{Method}

A multistage sampling technique was used to obtain a representative sample of schools in the selected LGAs across the state. The first stage involved the stratification of the state by senatorial zones. The distribution of these LGAs covered both urban and rural areas of the state. The second stage was the purposive selection of the three urban LGAs each of the three senatorial zones. The third stage was to randomly selection 2 LGAs from each of the three senatorial zones. The research covered all available public primary and secondary schools in the nine selected LGAs in Kaduna State. Reconnaissance survey was carried out, inventory of the existing public schools was obtained from state's Ministry of Education, Science and Technology (MOES\&T) and administrative map from Kaduna Sate Geographic Information Services (KADGIS). The physical assessment of the educational facilities was carried using Educational Facility Assessment Form (EFAF) and in order to avoid biasness Likert scale was introduced (from poor (1) to excellent (5)). The data was collected within 2017/2018 academic session.

\section{RESULTS}

\section{Availability of Public Schools}

The available educational facilities in the nine selected LGAs are key to understanding the types of schools and the nature of the distribution of these facilities. One thousand nine hundred and seven (1907) public schools were located and identified in the nine LGAs selected in Kaduna State (Table.1). 85.7\% of the available public schools are primary schools while $14.3 \%$ are secondary schools. The implications of these are that less children advances from primary education to secondary education. This is in agreement with the findings of the KSBS (2018) that there is $19 \%$ dropout rate in primary education and $34 \%$ dropout rate in junior secondary education in the state.

There are 109 number of public primary (59) and secondary (50) schools are not identified or located from list obtained by the MOES\&T as existing schools. There are 594 public schools in the three selected LGAs in Kaduna South Senatorial Zone (KSSZ) while Kaduna Central Senatorial Zone (KCSZ), have 554 public schools and Kaduna North Senatorial Zone (KNSZ) have 759 public primary and secondary schools in the three selected LGAs. The analysis of the available schools at the senatorial zones reveals that KNSZ have more schools representing 39.8\% than KCSZ (29.1\%) and KSSZ (31.1\%).

There are insufficient of junior and senior secondary schools in the three senatorial zone of the state. This might be the reason for the high number of drop out in secondary schools in Kaduna State. These findings support the request from people within and outside the state that there is need for more schools mostly in rural areas (Nwogu, 


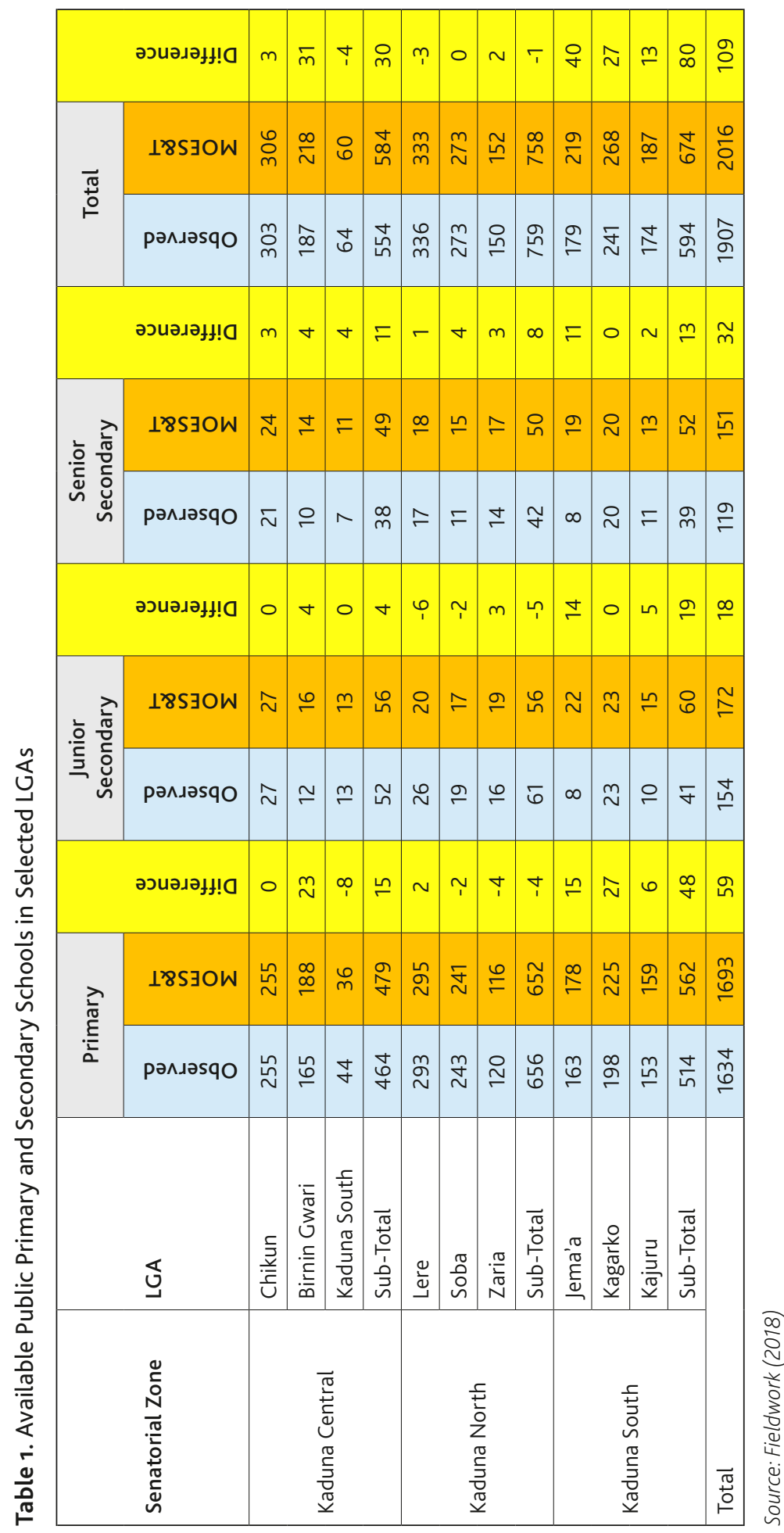


2015). $4.2 \%$ of the school do not have any structure thus meaning that the children either study or taught under tree or open space (Figure $2 \mathrm{a}, 2 \mathrm{~b}$ and $2 \mathrm{c}$ ). This finding is alarming as over $95 \%$ of the schools are primary schools and if all the children assumingly complete primary education and advances to secondary school. Then, 154 junior secondary schools will not be able to enroll or admit pupils from 1634 primary schools.

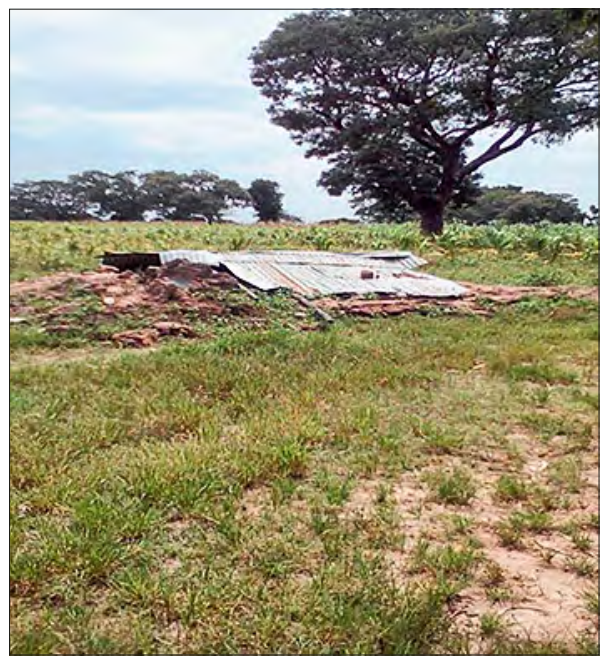

Figure 2a: LGEA Primary School Kwanan, Lere LGA

Source: Fieldwork (2018)

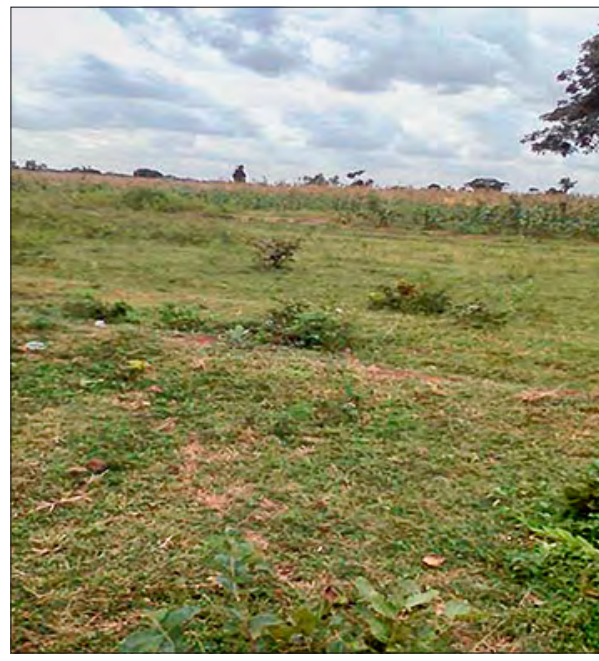

Figure 2b: UBE Primary School, Sabon Layi in Lere LGA Source: Fieldwork (2018)

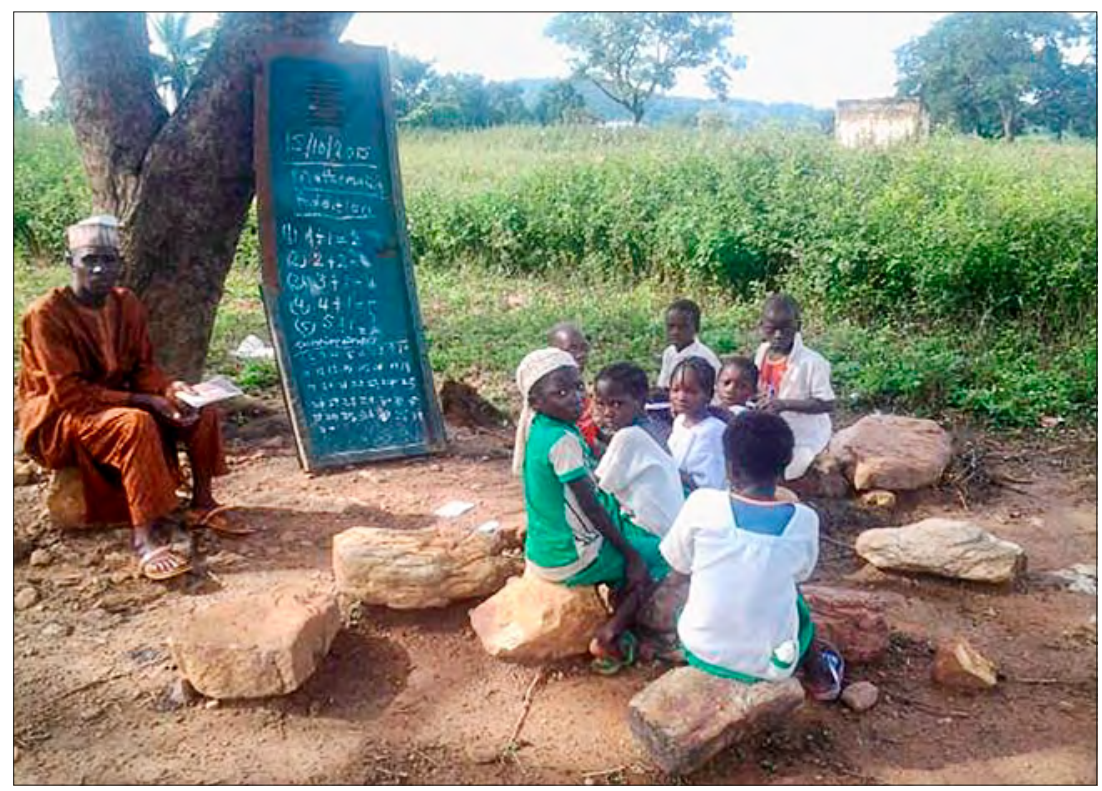

Figure 2c: UBE Primary School, Chiki Gari Kuchi, Kagarko LGA Source: Fieldwork (2018) 


\section{Conditions of Educational Facilities}

This section started with examining the capacity of the facilities in order to ascertain if it affects the conditions of the facilities such as number of students, teachers, classroom and age of school.

Capacity of Educational Facilities: There are 626,338 students in the nine selected LGAs of which Kaduna North Senatorial Zone (KNSZ) have 44.42\%, Kaduna Central Senatorial Zone KCSZ 33.80\% and KSSZ 21.78\%. It also shows that Chikun LGA has the highest number of students $(111,247)$ which is followed by Lere LGA with 108,120 students while Kaduna South LGA have the least 34,069 and Kajuru LGA with 38,115 (Table 2). The survey further reveals that there are 14,076 staff with $76.66 \%$ teaching staff and $23.34 \%$ non-teaching staff. It observes that there are 6,572 blocks and 10,821 classrooms, Kaduna South Senatorial Zone (KNSZ) have the highest number of classrooms $40.26 \%$ which is followed by KCSZ $31.07 \%$ and KSSZ have the lowest $28.67 \%$ (Table 2). The survey also shows that KSSZ have $37.63 \%$, KNSZ $35.5 \%$ and $26.87 \%$ of the blocks. It further exposes that KNSZ have the highest (64) average number students per classroom, which is KCSZ 63 and KSSZ have the lowest of 44 while the average total number of students per classroom is 58 .

Table 2. Distribution of Students, Staff, and Classrooms

\begin{tabular}{|l|c|c|c|c|c|c|c|}
\hline LGA & $\begin{array}{c}\text { No of } \\
\text { Student }\end{array}$ & $\begin{array}{c}\text { Teaching } \\
\text { Staff }\end{array}$ & $\begin{array}{c}\text { Non- } \\
\text { teaching } \\
\text { staff }\end{array}$ & $\begin{array}{c}\text { No of } \\
\text { Staff }\end{array}$ & $\begin{array}{c}\text { No of } \\
\text { Block }\end{array}$ & $\begin{array}{c}\text { No of } \\
\text { Classroom }\end{array}$ & $\begin{array}{c}\text { Average } \\
\text { Students/ } \\
\text { Classroom }\end{array}$ \\
\hline Zaria & 74610 & 914 & 222 & 1136 & 709 & 1505 & 50 \\
\hline Lere & 108120 & 1858 & 525 & 2383 & 720 & 1549 & 70 \\
\hline Soba & 95479 & 1951 & 490 & 2441 & 904 & 1303 & 74 \\
\hline Sub-Total- KNSZ & 278209 & 4723 & 1237 & 5960 & 2333 & 4357 & 64 \\
\hline Birnin Gwari & 66415 & 929 & 405 & 1334 & 419 & 1044 & 64 \\
\hline Chikun & 111247 & 1723 & 300 & 2023 & 1106 & 1071 & 104 \\
\hline Kaduna South & 34069 & 668 & 389 & 1057 & 241 & 1247 & 28 \\
\hline Sub-Total- KCSZ & 211731 & 3320 & 1094 & 4414 & 1766 & 3362 & 63 \\
\hline Kajuru & 38115 & 836 & 212 & 1060 & 563 & 949 & 41 \\
\hline Kagarko & 48689 & 1014 & 491 & 1505 & 1420 & 1175 & 42 \\
\hline Jemaá & 49594 & 898 & 239 & 1137 & 490 & 978 & 51 \\
\hline Sub-Total- KSSZ & 136398 & 2748 & 942 & 3702 & 2473 & 3102 & 44 \\
\hline Total & 626338 & 10791 & 3273 & 14076 & 6572 & 10821 & 58 \\
\hline
\end{tabular}

Source: Fieldwork

The implications of this is that the classrooms are overcrowded and the facilities are overstressed (Table 2 and Figure 3). This finding shows that educational facilities are not operated under the required minimum standards of having not more than 35 students per classroom. 


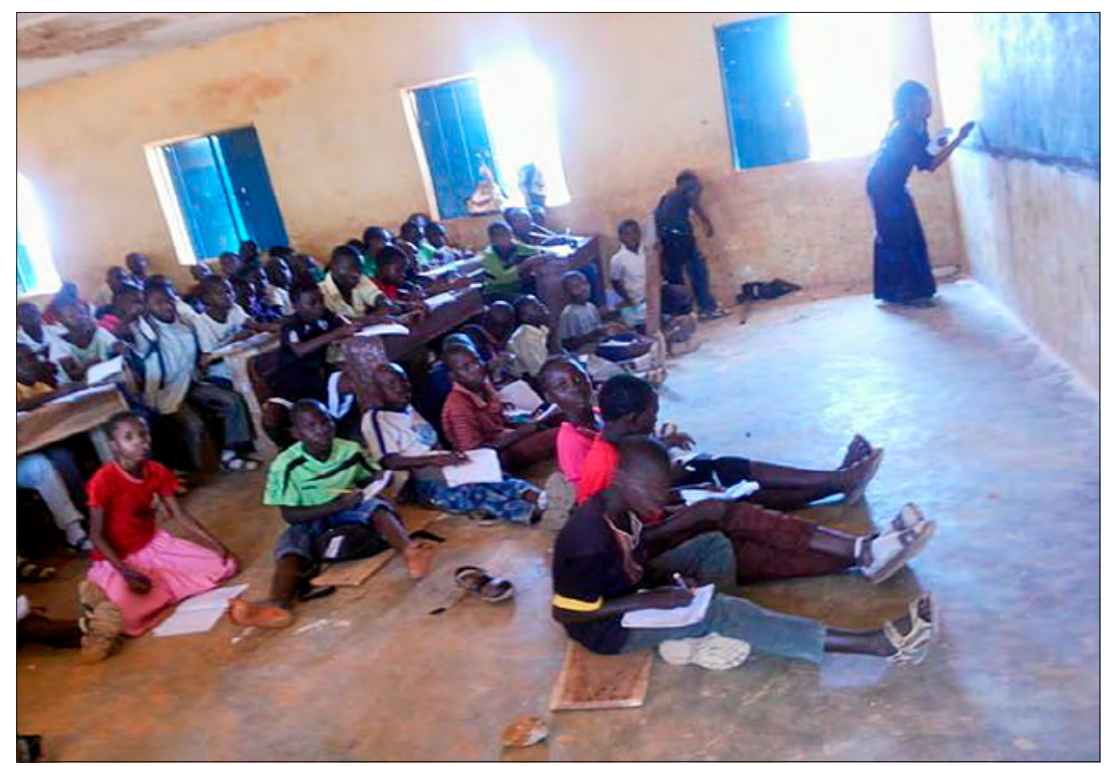

Figure 3. Government Junior Secondary School (GJSS), Romi, Chikun LGA Source: Fieldwork (2018)

Age of Schools: The age of the school building is revealed as a factor to student achievement. It also shows that the age of building in and of itself is usually not an important factor in influencing student attendance or enrollment as $95 \%$ of the older schools have more students. This is in agreement with the findings of Earthman (2002) that age of school building does not affect students' performance, but the building components that are necessary for good student learning are usually absent in older buildings. Further probe exposes that students prefers newer building (bricks or block) because of poor maintenance older school buildings. The survey shows that older buildings usually do not have the main attributes of a modern building that are associated with a positive physical environment conducive to student learning.

The older school buildings are mostly mud building $67 \%$ while newer buildings are blocks and bricks. The survey also reveals the urban LGAs namely Kaduna South, Jemaá and Zaria LGAs have least numbers of mud while rural LGAs having more (Figure 4). Many building facilities that are necessary for proper learning environments are simply absent in older buildings, but are present and functioning in new buildings. Such as ceiling, metal doors and windows.

Conditions of Educational Facilities: The capacity of the facilities gave a deeper understand of its conditions. The conditions were grouped the facilities into four (4) to enable a good coverage of all educational facilities in the area namely; classroom furniture, physical facilities, sanitation and health and security and sports.

Conditions of Classroom Furniture: Zaria LGA have the highest score (3.2) in conditions of classroom and closely followed by Kaduna South (2.95) and Jemaá LGA (2.9). Kagarko, Lere and Soba scored least in conditions of roof while Kaduna South, Zaria and Jemaá LGAs have leading scores of 4, 3.8 and 3.6 as shown in Figure 5. Soba LGA 


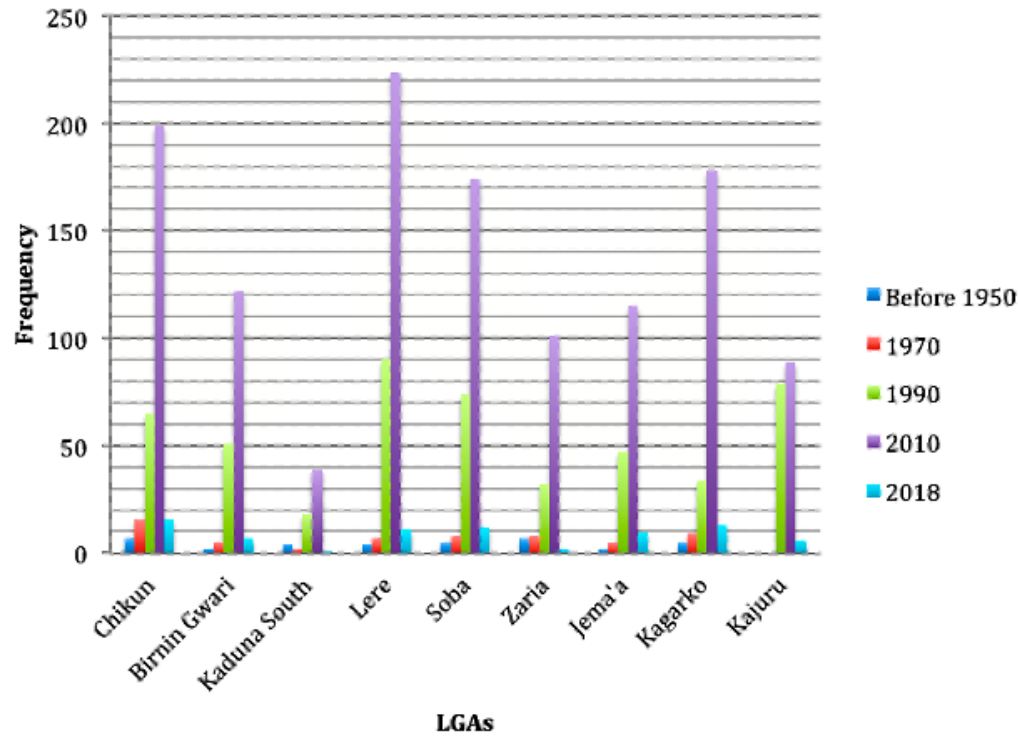

Figure 4. Age of Educational Facilities Source: Fieldwork (2018)

have least scores of 2.0 for conditions of paint (Figure 6a and 6b) while Kagarko and Kajuru LGAs follows with 2.4 and Kaduna South LGA have the highest scores of 3.2 while Zaria and Jemaá LGAs closely follows with 3.0. This implies that the urban LGAs have roof, floored and painted classroom than rural LGAs.

The survey further reveals that Kaduna South LGA have the highest scores of 2.8 and closely followed by Zaria and Jemaá LGAs with 2.7 and 2.6 on conditions of seats and

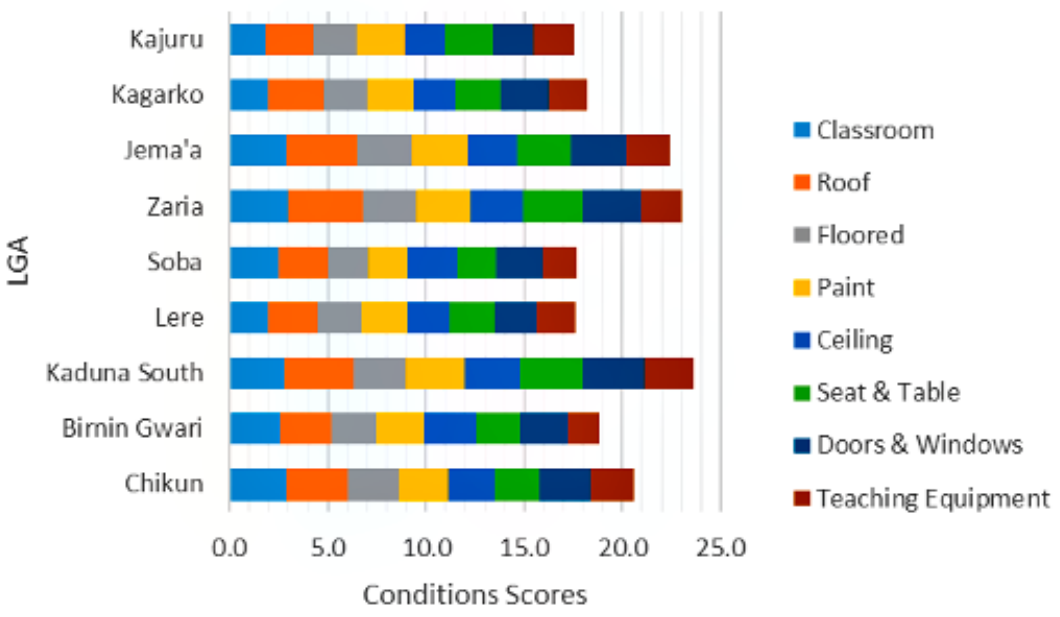

Figure 5. Conditions of Classroom Furniture Source: Fieldwork (2018) 


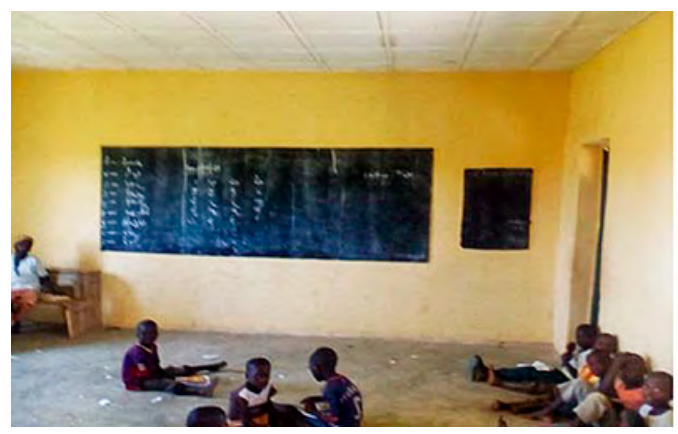

FIGURE 6a: LGEA Primary School, Ungwan Tudu, Soba LGA

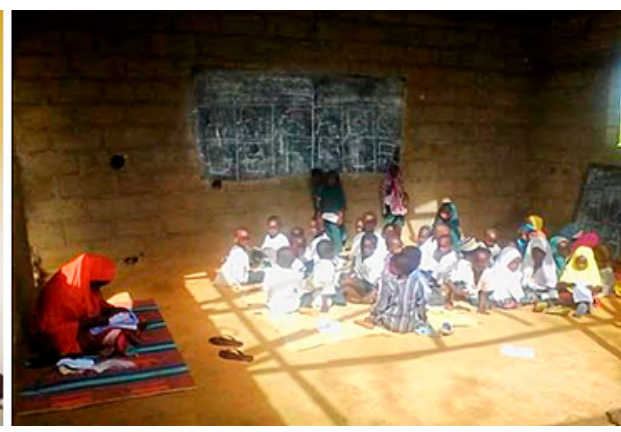

Figure 6b: LGEA Ungwan Sarki, Soba LGA

tables while same as obtained for conditions doors and windows (3.2,3.1,3.05). However, Kaduna South LGA scored highest (3.0) on the conditions of ceiling and followed by Birnin Gwari LGA (2.9) then Zaria and Jemaá LGAs.

The survey also reveals that Birnin Gwari, Soba, Kajuru and Kagarko LGAs have the lowest scores in teaching equipment, which includes blackboard, writing and playing materials. This implies that classroom furniture's are more in the urban LGAs of Kaduna South, Zaria and Jemaá. A further probe reveals that the doors and windows in some schools were replaced in June 2017 by KDSG but the students and the host community while playing football within the school have spoilt it within three months. This finding is in agreement with the finding of Mojela (2013) identified several factors that contribute to the deplorable conditions of public-school facilities in South Africa which includes vandalism. Kaduna South LGA have the best followed Zaria and Jemaá LGAs in overall conditions of classroom furniture while Lere, Soba Kajuru and Kagarko LGAs have poorest conditions of classroom furniture. Teaching equipment and ceilings have the lowest scores in condition and does require attention.

Conditions of Physical Facilities: Zaria LGA have the highest scores of 3.9 in the conditions of building facilities which is followed by Kaduna South LGA (3.30) and Jemaá LGA (2.9) while Kagarko LGA is last with 2.3 followed by Soba and Birnin Gwari LGAs with 2.4. Zaria LGA have the highest score of 3.3 in conditions of staffroom while Birnin Gwari LGA have the lowest of 1.3 which is followed by Soba LGA with 1.5 (Figure 7). Kaduna South LGA have the highest score in the conditions of store in public schools, which is followed by Zaria LGA with 2.5 and Soba LGA have the lowest (1.4). Lere LGA have the lowest scores of 1.1 in conditions of libraries which is closely followed by Soba LGA (1.2) and Kaduna South (2.7), Zaria (2.6) and Chikun (2.5) LGAs are the leaders.

Kaduna South LGA have the highest score (2.8) in the conditions of laboratory in public schools, which is followed by Zaria LGA with 2.6 and Kajuru LGA have the least (1.2) followed by Kagarko LGA. The survey observes that Lere, Kagarko and Kajuru LGAs have worst workshop in terms of the conditions while Kaduna South and Zaria LGAs have better workshops in public schools. This implies that the physical facilities attract school aged children to schools and also lead parents to believe that education levels are better in such schools. This may be attributed to the reasons why there are high rates of dropout in public schools in rural LGAs. Kiptum (2018) concluded that good ed- 


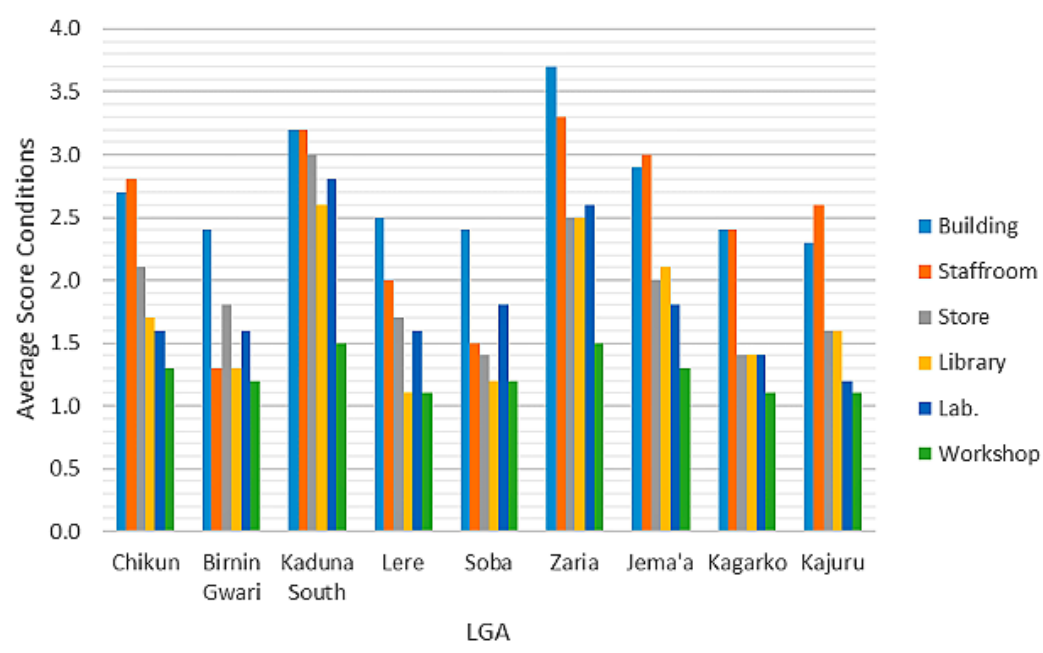

Figure 7. Conditions of Physical Facilities Source: Fieldwork (2018)

ucational facilities are very important for teachers and students to enjoy teaching and learning.

Conditions of Sanitation and Health Facilities: Kaduna South LGA have the highest in the conditions of water facilities in public schools while Kajuru and Birnin Gwari LGAs have the lowest scores of 1.6 against 5 point for excellent conditions (Figure 8). The survey also reveals that Lere LGA have the least condition of toilet facilities while Kaduna South LGA have the highest. Further probe reveals that Lere, Soba, Kajuru, Kagarko and Birnin Gwari LGAs have no wash hand in their toilets.

The survey exposes that Kaduna South and Zaria LGAs have first Aid facilities but are not well maintained and that $85 \%$ of the drugs are expired. The survey further re-

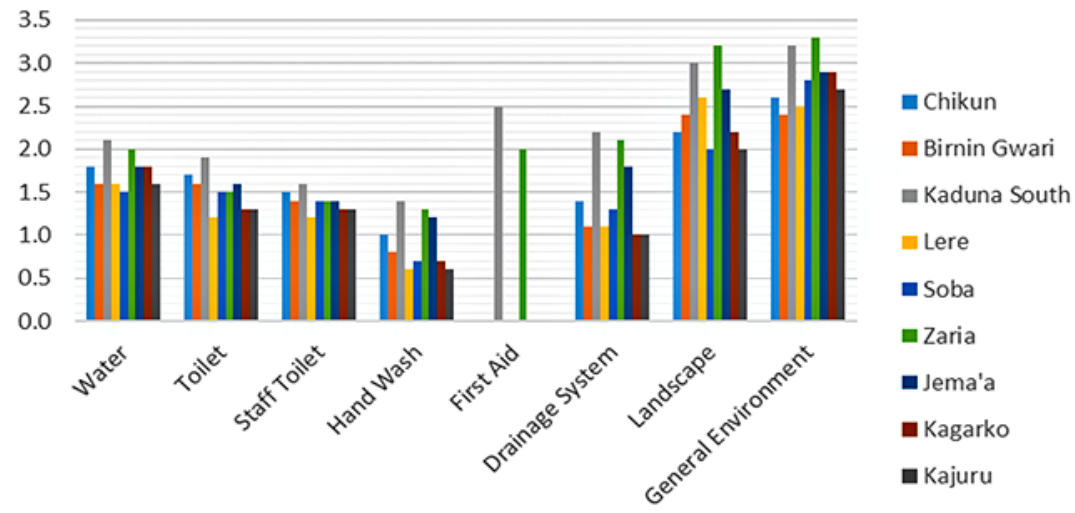

Facilities

Figure 8. Conditions of Sanitation and Health Facilities Source: Fieldwork (2018) 
veals that many of the public schools located in the rural LGAs do not have drainage systems while Zaria LGA have the best drainage systems. These drainage systems are crucial for environmental control and protection. The survey further reveals that most primary and secondary schools (68\%) lack this important facility as well as a good landscape, which would have help in reducing the devastating effects of erosion and flooding. This is in agreement with the findings of Izobo-Martins et al. (2014). The survey shows that Zaria LGA have the highest in the general environment of the public schools while Birnin Gwari and Lere LGAs have least maintained environment.

Conditions of Security and Sport Facilities: The survey observes that Kaduna South LGA have highest score in fence, gate and gatehouse condition which closely followed by Zaria and Jemaá LGAs (Figure 9). Fence, gate and gatehouses are mostly classified as most important facility in security of life and properties.

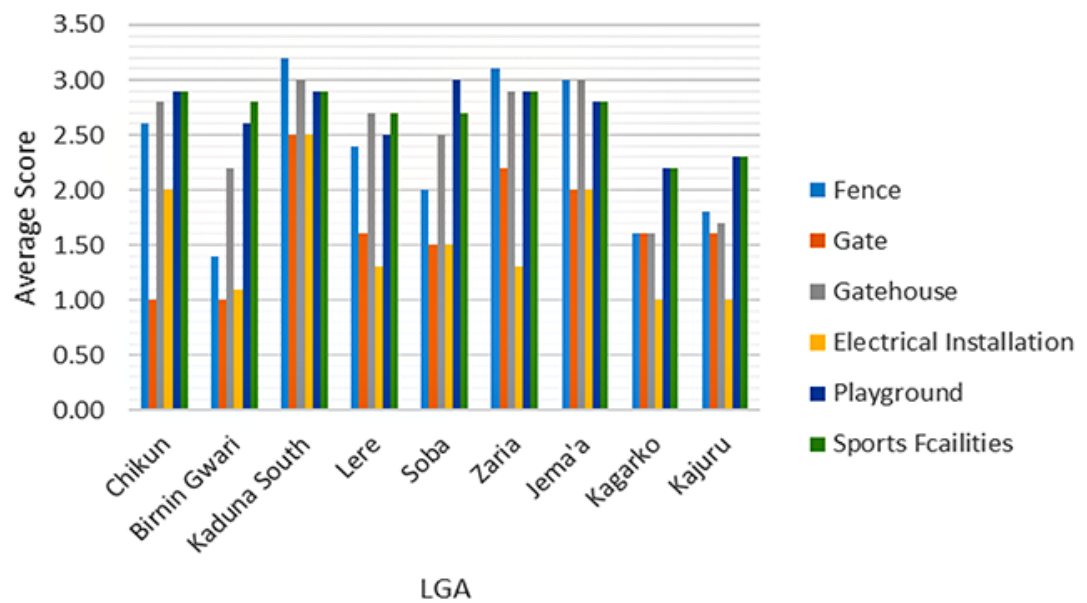

Figure 9. Conditions of Security and Sport Facilities

Source: Fieldwork (2018)

This implies that the schools are not secured and might lead to withdrawal of children from school. The conditions of electrical installations are very poor as $86,1 \%$ public schools do not have power supply. While $88.5 \%$ of the school need urgent maintenance attention on the existing power supply (Figure 9). Many of these public schools are not paying power bill as reported by the head teachers. This is in agreement with the findings of IzoboMartins et al. (2014). However, Garba and Aminu (2019) ascertained that constant power supply to educational facilities does improve pupils' learning level. The survey shows that Lere LGA have the highest score in playground while Kagarko and Kajuru LGAs scores the lowest. The survey also shows that Zaria, Chikun and Kaduna South LGAs have the highest scores in sports facilities conditions. This may be because most schools on longer have annual school inter-house sports competitions. This is attributed to lacking of funding from government and economy hardship on the part of the parents.

General Conditions of Facilities: The survey shows UBE, Ungwan Dakka in Birnin Gwari and LGEA Primary School, Magungunain Kajuru LGA have the least condition 
of facilities in all the public primary school. While UBE Primary School, Rafin Yashi in Zaria LGA, LGEA Primary School in Kaduna South LGA and LGEA, Kufana in Kajuru LGA are highest scoring primary schools. This implies that urban LGAs are having better facility conditions. The survey detects that GJSS Jukun, Kofar Jatau have the least score of 1.7among the Junior Secondary Schools in Zaria LGA while GJSS Gure scored 1.3 in Lere LGA, and JSS, Richifa in Soba LGA (1.2). Thus, JSS, Richifa in Soba LGA scored the least in all JSS in KSSZ. In KCSZ, Tabannni in Birnin Gwari LGA (2.0), GJSS Kiduna (2.3) in Chikun LGA and Namadi Sambo Junior Secondary School, Kabala West, Kaduna South LGA (2.8). Despite, Namadi Sambo Junior Secondary School, Kabala West, Kaduna South LGA scoring in least Kaduna South LGA the analysis reveals that its far better than $58 \%$ of all the JSS in KCSZ.

The survey discovers that GJSS Kauru scored 1.6 which among the JSS in semi-urban towns. The survey reveals that Government College, Kurmin Mashi in Kaduna South LGA (4.5), which is closely followed by GSS Kafanchan (4.4) and GSS Doka Lere in Lere LGA (4.1), Barewa College, Zaria in Zaria LGA (4.1). GSS Kofar Gagan in Zaria LGA have the least scores of 1.4, while GSS Dinye Soba in Soba have 1.6 and GSS Randagi in Birnin Gwari LGA (1.7). This finding falls below the SDG 4 target to build and upgrade education facilities that are child, disability and gender sensitive and provide safe, nonviolent, inclusive and effective learning environments for all (UNESCO, 2017b; 2018).

\section{Implications of Poor Conditions of Facilities in Schools}

The survey has revealed the conditions of the available facilities in public primary and secondary schools in the state. However, some of the facilities are below acceptable standards and, in some cases, non-existent. The survey shows inadequacy of functional public sanitary facilities in $13.9 \%$ of the schools and hence the open defecation is common in such public schools. It also discovers that $58.3 \%$ of the schools do not provide water closets for the students' toilets but provide pit latrines and other unconventional options.

The survey discovers that the conditions of fence and gatehouse are very poor and only $15 \%$ of the schools with fence are in good conditions. The survey also exposes that the absence of fence in many schools have led to the stealing and damaging of some of the school's facilities and members of the host communities use the playing ground for football or even hosting meeting and cultural feast. $85.6 \%$ of the schools do not have access to water, this percentage of schools with poor access to water should be improved upon. This will help reduce the cases of diseases outbreak in schools and especially in schools in rural area. $68.4 \%$ of the head teachers agreed that the existing facilities has not been properly maintained and the main reason is shortening of funds.

Thirty-five percent of the available schools are less than 20 years old but the conditions of the facilities are not commensurate, since some of the older schools have better maintained and functional facilities. The survey further exposes that the conditions of power supply and electrical installations is very poor in $24.35 \%$ of the schools and $77 \%$ of the schools either requires urgent repairs or replacement. Further probe into finding the factors affecting the conditions of facilities, which reveals that attitude, lack of mon- 
itoring on the part of MOES\&T, poor maintenance culture and insufficient funding of maintenance works in these schools are primarily responsible for the poor conditions of these educational facilities in Kaduna State.

School buildings are part of a society's asset and infrastructure, because they could be used for a long time. However, at age 40, most buildings start deteriorating rapidly, even if all original components are replaced (Mojela 2013). This conforms with the findings of Izobo-Martins et al. (2014) and Mojela (2013) that user attitude, poor maintenance culture, no sense of ownership by stakeholders, inadequate funding and vandalism in these schools were observed as primary factors responsible for the poor conditions of these facilities. The survey exposes that not even one school out of the 1906 surveyed have a maintenance officer or any expert in facility management. This is in agreement with the findings of Zubairu (2010) that epileptically functioning of facilities in the public buildings in Nigeria to poor and lack of maintenance. Most schools are lacking in important facilities and the existing ones are poor conditions and are not properly maintained.

The implications of poor conditions of facilities in public schools are the outcome inadequate government intervention, no sense of ownership by students and teachers, inadequate funding, and vandalism. This might be one of the reasons why many parents prefer private schools to public school especially in urban areas. Furthermore, lack of maintenance, neglect, deferred maintenance and overcrowding are the other likely thing contributing to the poor conditions in public schools.

\section{Remedies to Poor Conditions of Facilities in Schools}

The private sector and community leaders in conjunction with media firms should educate all on the need for change in user attitude and maintenance culture from students and staff as well as residents in the host communities. There is need for quick response from the State's MOES\&T to improve the management and maintenance of educational facilities in the state. And this can be achieved by the implementation of the UNESCO's benchmark for funding of education, which demands $26 \%$ annual budget and $6 \%$ of the gross domestic product be invested in education. LGAs of Kajuru, Kagarko, Soba, Lere, Chikun and Brinin Gwari requires attention in fence wall, classroom, water, sanitation and health. Kaduna South, Lere and Kajuru LGAs require sports facilities and equipment. The State government should provide sufficient funding for timely maintenance works in the public schools. MOES\&T should engage the services of facility management firms to manage and maintenthe facilities especially in Kagarko, Kaju$\mathrm{ru}$, Lere and Brinin Gwari LGAs. There is the need for the upgrading of existing toilets and building of more toilets for student (male/female) and teachers, while water should be provided in all the public schools in the state. 


\section{CONCLUSION}

The conditions of educational facilities in the selected LGAs in Kaduna State has proven not to meet the expected minimum standards as required by Federal Ministry of Education Thus, the it recommends that actors in the educational sector in Kaduna State should carry out Annually condition assessment of schools in the state. The state government should also increase its funding for the management of educational facilities in the public schools and building new structures. By the implication of the UNESCO's benchmark of demands $26 \%$ annual budget and $6 \%$ of the gross domestic product be invested in education and develop a database for public schools and educational facilities in the state.

\section{REFERENCES}

Abdullahi, I. and Wan Zahari, W. Y. (2015) State of Physical Facilities of Higher Education Institutions in Nigeria, International Journal of Scientific and Research Publications, 5 (4).

Ada, N. A. (2005). Towards Meeting Science and Technology Manpower Demand for National Development: Indicator from Benue State, In A. Lyam, Y. A. Ochefu, J. A., Sambe and A. M. Adejo (Eds), Benue State in Perspective, Aboki Publishers, Makurdi. Adamu, H. D., Baba-Gana, L. A. and Emmanuel, I. P. (2015). Assessment of the Implementation of the Universal Basic Education Programme (UBE) on School Infrastructure in Potiskum, Yobe State, Nigeria, Sahel Analyst: Journal of Management Science, 13 (2).

Adeyemi, T. (2011). A Comparative Study of Students, Academic Performance in Public Examination in Secondary Schools in Ondo and Ekiti States, Nigeria, Current Research Journal of Economic Theory, 3 (2), 26-42.

Akpu, B. (2012). An Analysis of Spatio-Temporal Growth of Kaduna Metropolis and Its Environmental Consequences in Kaduna State, Unpublished PhD Thesis, Geography Department, Ahmadu Bello University, Zaria.

Archibong, B., Modi, V. and Shepa, S. (2015). Geography of Infrastructure Functionality at School in Nigeria: Evidence from Spatial Data Analysis Across Local Government Area, Applied Geography, 1 (2), 176-183.

Ayeni, A. J. and Adelabu, M. A. (2012). Improving Learning Infrastructure and Environment for Sustainable Quality Assurance Practice in Secondary Schools in Ondo State, South-West, Nigeria, International Journal of Research Studies in Education, 1(1).

Bako, A. R., Maiwada, A., Abubakar, M. and Akwo, J. S. (2016). Analysis of the Levels of Under-Five Mortality in Kaduna State, Nigeria, Duste Journal of Pure and Applied Sciences (DUJOPAS), 2 (2).

Bhunia, G. S., Shit, P. K. and Duaru, S. (2012). Assessment of School Infrastructure at Primary and Upper Primary Level: A Geospatial Analysis, Journal of Geographic Information System, 4, 412-424. 
Earthman, G. I. (2002). School Facility Conditions and Student Academic Achievement, Williams Watch Series of UCLA's Institute for Democracy, Education, and Access, Virginia Polytechnic Institute.

Fabiyi, O. O. and Ogunyemi, S. A. (2015). Spatial Distribution and Accessibility to Post Primary Educational Institution in Ogun State, Southwestern Nigeria: Case Study of Yewa South Local Government Area, Nigeria, Journal of Scientific Research and Reports, 5 (7), 542-552.

Fabunmi, M. (2005). Perspective in Education Planning, Awe Mark Industry Printer, Washington DC

Garba, U. and Aminu, H. A. (2019). Assessment of Teachers-Pupils Perceptions on Use of Digital Images in Teaching Reading Fluency Skill in Sotoko Metropolis, International Journal of Arts and Social Science, 2(1), 21-28.

Hena, M. K. (2014). Contribution of Motor Vehicle Emissions to Air Pollution in Kaduna, Nigeria, Unpublished PhD Thesis, Geography Department, Ahmadu Bello University, Zaria, Nigeria.

Izobo-Martins, O. O., Dare-Abel, O. A. and Kunle, A. V. (2014). Assessment of Infrastructural Condition in Public Secondary Schools, Ogun State Nigeria, International Conference on Infrastructural Development in Africa (ICIDA) held at the Obasanjo Presidential Library, Abeokuta.

Kaduna State Bureau of Statistics (KSBS) (2018). Kaduna State Annual School Report 2017, KSBS, Kaduna.

Kaduna State Government (KDSG) (2017). Kaduna State Infrastructure Master Plan 20182050, Providing the Infrastructure to Accelerate Our Development, Kaduna State Ministry of Works Housing and Transportation, Kaduna State Press, Kawo, Kaduna.

Kiptum, J. K. (2018). Influence of School Physical Environment on Teachers' Satisfaction in Selected Public Primary Schools in Elgeyo Marakwet County, Kenya, PhD Thesis, Department of Education, Kenyatta University, Kenya.

Mojela, T.W. (2013). Assessment of the Effectiveness of Public Schools Infrastructure Maintenance System in the Gauteng Province, M. Tech Thesis in Construction Management of the Department of Construction Management.

Musa, D. H. and Mohammed, B. B. (2013). An Analysis of Spatial Distribution of Primary and Secondary Schools in Bida Town, Nigeria, Abuja Journal of Geography and Development, 3 (2).

National Bureau of Statistics (NBS) (2017). Annual Abstract of Statistics, NBS, Abuja. National Population Commission (2009). Federal Republic of Nigeria official Gazette, Lagos, the Federal Government Printers, 24 (94), 187.

Nwude, M. O. (2006). A Sustainable Option for Solid Waste Management in Kaduna State, Unpublished MSc Dissertation, Geography Department, Ahmadu Bello University, Zaria, Nigeria.

Nyam-Jim, L. G. (2016). Location Analysis and Creation of Geo-Database For Public Secondary Schools in Kaduna Education Zone, Kaduna State, Nigeria, MSc Dissertation, Geography Department, Ahmadu Bello University, Zaria, Nigeria. 
Olamiju, I. O. and Olujimi, J. (2011). Regional Analysis of Locations of Public Educational Facilities in Nigeria: The Akure Region Experience, Journal of Geography and Regional Planning, 4 (7), 428 - 442.

UNESCO (2006). Literacy for Life. Paper Commissioned for the Education for all (EFA) Global Monitoring Report 2006, UN, USA.

UNESCO (2017a). Education for All Global Monitoring Report (EAGMR).

UNESCO (2017b). Quick Guide to Education Indicators for SDG 4, UNESCO Institute for Statistics, Canada.

UNESCO (2018). SDG4 Data Book: Global Education Indicators 2018, UNESCO Institute for Statistics, Canada.

UNICEF (2013). Fact of the Week: 2013, Available from: http://www.unicef.org/ factoftheweek/index, Accessed Oct 24, 2018.

Zubairu, S. N. (2010). The National Building Maintenance Policy for Nigeria: The Architects' Perspective, Compilation of Seminar Papers presented at the 2010 Architects Colloquium - Architecture and the National Development Agenda III, Architects Registration Council of Nigeria, Lagos, 1-12.

\section{CONFLICTS OF INTEREST}

The authors declared no potential conflicts of interest with respect to the research, authorship, and/or publication of this article.

(C) 2020 by the authors. This article is an open access article distributed under the terms and conditions of the Creative Commons Attribution (CC BY) license (http://creativecommons.org/licenses/by/4.0/). 